\title{
RANCANG BANGUN SISTEM INFORMASI SATUAN KREDIT PARTISIPASI MAHASISWA FAKULTAS TEKNIK UNIVERSITAS UDAYANA
}

\author{
I Gede Agus Satya Dharma ${ }^{1}$, Duman Care Khrisne ${ }^{2}$, I Made Arsa Suyadnya ${ }^{3}$ \\ Program Studi Teknik Elektro, Fakultas Teknik, Universitas Udayana Denpasar - Bali \\ Email : agussatya06@gmail.com ${ }^{1}$, duman@unud.ac.id $^{2}{ }^{2}$ arsa.suyadnya@unud.ac.id $^{3}$
}

\begin{abstract}
ABSTRAK
Satuan Kredit Partisipasi (SKP) merupakan sistem penghargaan terhadap mahasiswa Universitas Udayana atas partisipasinya dalam kegiatan kemahasiswaan baik dalam bidang akademis maupun non akademis. SKP ini merupakan salah satu persyaratan yang harus dipenuhi oleh setiap mahasiswa ketika akan mengikuti yudisium. Pada Fakultas Teknik Universitas Udayana, ada beberapa data SKP mahasiswa yang tidak tersimpan dengan baik, sehingga data SKP hilang dan membuat proses penginputan SKP mahasiswa menjadi bermasalah. Pada penelitian ini, sistem informasi yang dibangun akan digunakan untuk mengelola data SKP mahasiswa Fakultas Teknik Universitas Udayana. Sistem informasi ini dibangun dengan menggunakan bahasa pemrograman HTML, PHP dengan DBMS MySQL dan menggunakan Framework Bootstrap. Hasil dari pengujian System Usability Scale (SUS) yang diberikan kepada (20) user pengguna sistem ini, memperoleh nilai rata-rata 80,88 yang berarti memiliki nilai Adjective Ratings Excellent, Grade Scale B dan Acceptability Ranges Acceptable.
\end{abstract}

Kata Kunci : Akademis, informasi, mahasiswa, non akademis, Satuan Kredit Partisipasi (SKP), System Usability Scale (SUS)

\section{ABSTRACT}

Participation Credit Unit (PCU) is a system of appreciation to Udayana University's students for their participation in student activities in both academic and non academic fields. It is one of the requirements that must be met by every student in order to be allowed to follow graduation. At the Faculty of Engineering of Udayana University, there are some data of students' PCU that are not stored well, so the data get lost and make the process of inputting the PCU of students become problematic. In this study, the information system being built will be used to manage the PCU data of Faculty of Engineering students of Udayana University. This information system is built by using an HTML programming language, PHP with MySQL DBMS and by using the Bootstrap Framework. The results of the System Usability Scale (SUS) test given to (20) users of the system obtained an average value of 80,88 which means that the it has the values of Excellent Adjective Ratings, B Scale Grade and Acceptable Acceptability Ranges.

Keywords: Academic, information, non academic, Participation Credit Unit (PCU), student, System Usability Scale (SUS)

\section{PENDAHULUAN}

Satuan Kredit Partisipasi (SKP) merupakan sistem penghargaan terhadap mahasiswa Universitas Udayana atas partisipasinya dalam kegiatan ekstra kurikuler. SKP bertujuan untuk memberikan penghargaan atas partisipasi mahasiswa dalam mengembangkan kegiatan kemahasiswaan dalam bidang akademis maupun non akademis. Penerapan Satuan Kredit Partisipasi (SKP) mengacu pada buku pedoman (SKP). SKP akan diperhitungkan pada akhir studi (S1) sebagai syarat untuk dapat mengikuti yudisium di Universitas Udayana dan mahasiswa wajib memenuhi SKP minimal yang telah ditentukan [1].

Jumlah poin yang diperoleh oleh mahasiswa setelah mengikuti kegiatan kemahsiswaan di Universitas Udayana dipengaruhi dari jabatan yang diduduki dan ruang lingkup atau tingkat yang ada di Universitas Udayana. Setiap kegiatan di masing-masing tingkatan memiliki SK Panitia. SK Panitia berisi data 
panitia yang melaksanakan kegiatan beserta jabatannya masing-masing. Jika poin SKP yang dimiliki oleh mahasiswa sudah mencukupi, sesuai dengan status mahasiswa yang bersangkutan, maka mahasiswa yang bersangkutan dapat melakukan proses penginputan SKP. Mahasiswa menginput SKP untuk persyaratan mengikuti yudisium [1]. Idealnya data SKP mahasiswa terkumpul pada komisi SKP Himpunan. Namun pada Himpunan Mahasiswa Elektro Non-Reguler beberapa data SKP mahasiswa tidak tersimpan secara lengkap. Data SKP yang ada hanya beberapa SK panitia, beberapa piagam Bilteks dan beberapa piagam kegiatan. Data SKP yang dimiliki oleh Himpunan Mahasiswa Elektro Non-Reguler tidak lengkap karena ada beberapa ketua panitia yang tidak mengurus SK panitia, serta beberapa piagam kegiatan mahasiswa hilang karena beberapa kali berpindah tangan antar pengurus Himpunan Mahasiswa Elektro NonReguler.

Perkembangan teknologi informasi yang pesat saat ini tentunya dapat dimanfaatkan untuk mengatasai permasalahan mengenai SKP tersebut. Seperti pada penelitian yang dilakukan oleh Sukarata (2015) mengenai pembuatan sistem informasi satuan kredit kegiatan mahasiswa Politeknik Negeri Bali berbasis web. SIstem informasi ini dapat digunakan sebagai media penyimpanan data satuan kredit kegiatan mahasiswa secara online dengan database terpusat sehingga data yang diinputkan tidak ganda [2].

Terkait dengan permasalahan SKP pada Fakultas Teknik Universitas Udayana, pada penelitian ini dibangun sebuah sistem informasi satuan kredit partisipasi mahasiswa Fakultas Teknik Universitas Udayana yang dapat membantu Komisi SKP dalam melakukan proses penginputan data SKP mahasiswa dan dapat membantu keakuratan data SKP yang dimiliki oleh mahasiswa dan Komisi SKP Himpunan maupun Komisi SKP Senat. Berbeda dengan penelitian yang dilakukan oleh Sukarata (2015), sistem informasi satuan kredit partisipasi mahasiswa Fakultas Teknik Universitas Udayana yang dibangun tidak hanya dapat melakukan penyimpanan data SKP mahasiswa saja. Pada penelitian ini, sistem informasi yang dibangun dapat menampilkan aktivitas berita terbaru seputar kegiatan kemahasiswaan Fakultas Teknik Universitas Udayana. Selain itu, sistem informasi ini memiliki tampilan yang dapat menyesuaikan diri secara otomatis sesuai dengan perangkat yang digunakan untuk mengakses sistem informasi ini. Untuk mendapatkan transkrip SKP, sistem ini akan melibatkan beberapa user (pengguna) mulai dari mahasiswa, Komisi SKP Himpunan, Komisi SKP SMFT dan Kemahasiswaan. Seluruh proses penginputan, approve, hingga cetak transkrip SKP mahasiswa yang awalnya dilakukan secara manual, pada sistem informasi satuan kredit partisipasi mahasiswa Fakultas Teknik Universitas Udayana ini dapat dilakukan secara online, sehingga dapat mempercepat proses kepengurusan SKP mahasiswa.

\section{KAJIAN PUSTAKA}

\subsection{Sistem Informasi}

Sistem informasi adalah suatu sistem didalam organisasi yang mempertemukan kebutuhan pengelola transaksi harian, mendukung operasi, bersifat manajerial dan kegiatan strategi dari suatu organisasi dan menyediakan pihak luar tertentu dengan laporanlaporan yang diperlukan [3].

\subsection{Bootstrap}

Bootstrap merupakan salah satu framework CSS dengan proses desain website tidak dibuat dari nol, sehingga proses desain website lebih cepat dan mudah. Bahkan tanpa kita membuat skrip CSS sedikit pun, kita sudah dapat membuat sebuah website yang bagus. Bootrstrap juga dilengkapi dengan fitur responsive yang membuat website dapat dilihat dalam berbagai ukuran layar seperti Smartphone atau tablet dengan desain tetap teratur dan mengikuti ukuran layar [4].

\subsection{Usability Test}

Usability merupakan atribut kualitas yang menjelaskan atau mengukur seberapa mudah penggunaan suatu antar muka (interface). Usability diukur menggunakan lima kriteria yaitu learnability, efficiency, memorability, errors dan satisfaction [5].

\subsection{System Usability Scale (SUS)}

System Usability Scale (SUS)

merupakan salah satu metode pengujian sistem menggunakan skala likert yang didasarkan pada beberapa pernyataanpernyataan pilihan yang terbatas pada skala 5 atau 7. Sebagian item pertanyaan 
kuesioner mengindikasikan respon yang sangat positif dan sebaliknya. Hal ini dilakukan untuk mencegah respon bias dari responden. Dengan demikian, responden diharapkan bersedia untuk membaca dan mengisi kuesioner dengan lebih teliti. Itemitem kuesioner mencakup beragam aspek seperti dukungan pengguna, pelatihan, dan kompleksitas sistem. Oleh karena itu, kuesioner ini memiliki tingkat validitas tinggi untuk pengukuran usabilitas sebuah sistem. Adapun beberapa pernyataan kuesioner System Usability Scale (SUS) yang dapat dilihat pada Gambar 1 [6].

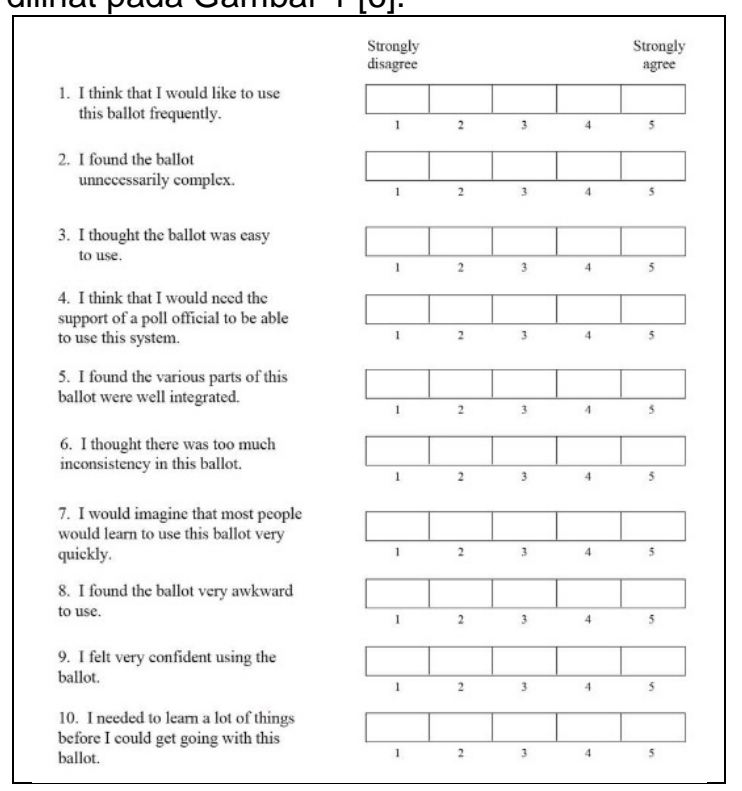

Gambar 1 System Usability Scale (SUS)

Penggunaan kuesioner SUS melibatkan minimal 20 pengguna yang melingkupi pengguna akhir (end user) hingga programmer sistem. Kuesioner SUS digunakan setelah responden berkesempatan menggunakan sistem. Pengukuran SUS dilakukan dengan menjumlahkan nilai tiap item. Nilai tiap item berada dalam rentang 0 sampai 4 . Untuk item nomor ganjil nilai item adalah hasil dari penilaian pengguna untuk item tersebut dikurangi satu. Untuk item nomor genap nilai item adalah hasil dari 5 (lima) dikurangi dengan nilai dari pengguna untuk item tersebut. Total skor 10 item kemudian dikalikan dengan bilangan 2,5 sehingga menghasilkan skor akhir dalam rentang $0-100$ [6].

Karena hasil nilai dari kuesioner SUS hanya menunjukkan dalam bentuk angka, banyak orang yang bertanya tentang seberapa tepatnya kata sifat yang dapat mewakili hasil nilai dari kuesioner SUS. Maka dibuatlah skala penilaian yang dapat mengetahui apakah sistem tersebut dapat diterima atau tidak dan mengetahui range nilai berdasarkan skala nilai sekolah. Adapun rentang nilai SUS yang dapat dilihat pada Gambar 2 [7].

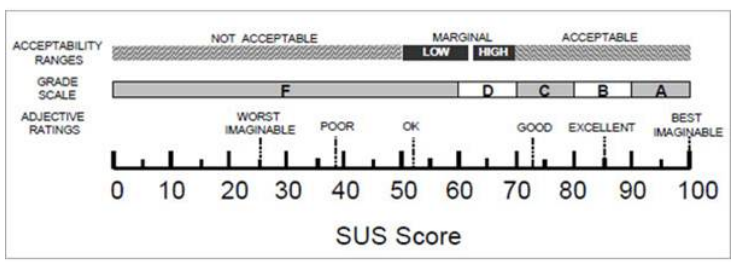

Gambar 2 Gambaran Rentang Nilai SUS

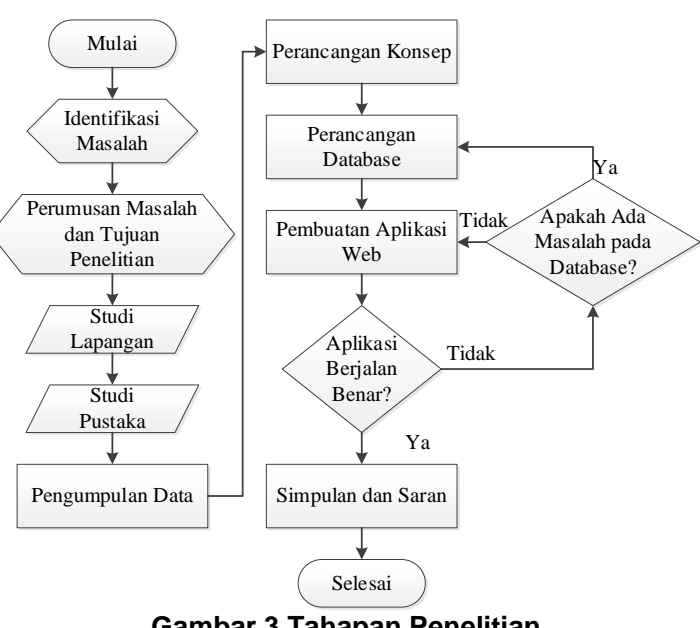

Gambar 3 Tahapan Penelitian

\section{METODE PENELITIAN}

Data penelitian ini bersumber dari Himpunan Mahasiswa Teknik Elektro Non-Reguler Fakultas Teknik Universitas Udayana. Jenis data yang digunakan adalah data sekunder yaitu berupa buku pedoman satuan kredit partisipasi, data SK kegiatan, piagam penghargaan sebagai panitia dan peserta kegiatan kemahasiswaan. Adapun tahapan penelitian dapat dilihat pada Gambar 3.

Sebagai langkah awal dalam penelitian ini, perlu dilakukan identifikasi masalah, kemudian dilakukan perumusan masalah dan membuat tujuan penelitian, lalu melakukan studi lapangan, kemudian melakukan studi pustaka, setelah itu melakukan pengumpulan data. Setelah memiliki rumusan masalah, tujuan penelitian dan data, kemudian dibuat rancangan konsep dalam bentuk Diagram Konteks, Data Flow Diagram (DFD) dan Entity Relationship Diagram (ERD). Setelah 
pembuatan konsep penelitian kemudian dilakukan perancangan database yang terstruktur untuk menentukan entitas, atribut dan relasi yang terjadi diantara masing-masing entitas. Setelah rancangan database selesai, dilanjutkan dengan pembuatan aplikasi web. Sistem informasi satuan kredit partisipasi mahasiswa Fakultas Teknik Universitas Udayana ini dibangun menggunakan responsive web design dengan framework bootstrap dan MySQL sebagai database. Setelah aplikasi dibuat, kemudian dilakukan pengujian sistem menggunakan metode pengujian System Usability Scale (SUS). Jika aplikasi tidak berjalan dengan benar, maka akan kembali ke proses pembuatan aplikasi web, jika ada permasalahan dengan database maka akan kembali ke tahap perancangan database. Setelah aplikasi berjalan dengan baik, maka dilakukan proses pembuatan simpulan dan saran. Dengan demikian penelitian selesai dilakukan.

\subsection{Gambaran Umum Sistem}

Sistem informasi satuan kredit partisipasi mahasiswa Fakultas Teknik Universitas Udayana ini dirancang untuk memberikan kemudahan kepada mahasiswa dan Komisi SKP dalam melakukan proses penginputan, pengecekan, pencarian dan cetak transkrip SKP. Melalui beberapa tahapan sebagai berikut.

Pertama, ketua kegiatan menginputkan informasi kegiatan pada sistem. Setelah informasi kegiatan diinputkan, kemudian ketua kegiatan menginputkan data absensi panitia. Setelah absensi panitia diinputkan, maka Kemahasiswaan akan membuat SK kegiatan yang berisi informasi kegiatan dan struktur kepanitian kegiatan tersebut. Setelah SK kegiatan dibuat oleh Kemahasiswaan, Komisi SKP Senat akan mengisi poin masing-masing SKP mahasiswa berdasarkan bidang, tingkat, bagian dan jabatan kegiatan. Kemudian mahasiswa akan melakukan proses penginputan SKP, dan Komisi SKP Senat akan mencetak transkrip SKP. Semua proses tersebut dilakukan dalam sistem.

Jika transkrip SKP sudah tercetak, Komisi SKP akan langsung menghubungi SMFT dan BPMFT untuk memperoleh tandatangan pengesahan transkrip SKP mahasiswa. Kemudian transkrip SKP mahasiswa yang sudah memperoleh tandatangan SMFT dan BPMFT akan diserahkan kepada mahasiswa yang bersangkutan untuk selanjutnya bertemu dengan PD III untuk memperoleh tandatangan. Apabila PD III sudah memberikan tandatangan dengan demikian proses penginputan SKP sudah selesai dilakukan. Adapun Gambaran umum sistem dapat dilihat pada Gambar 4.

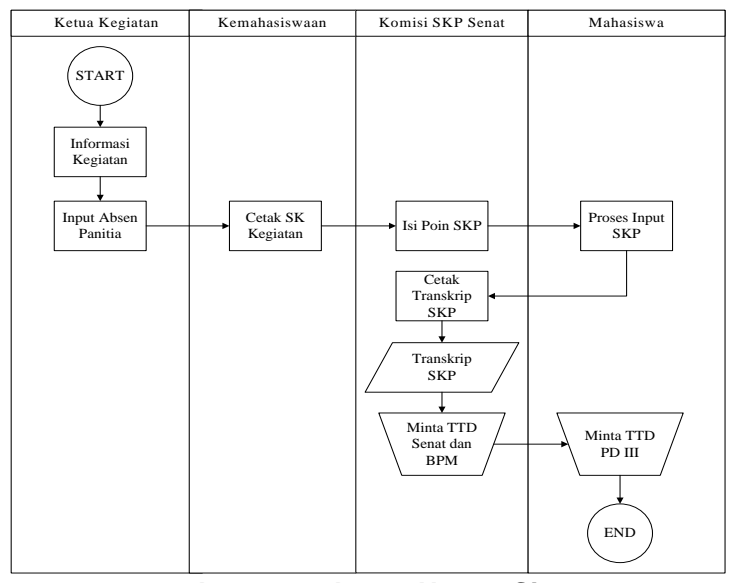

Gambar 4 Gambaran Umum Sistem

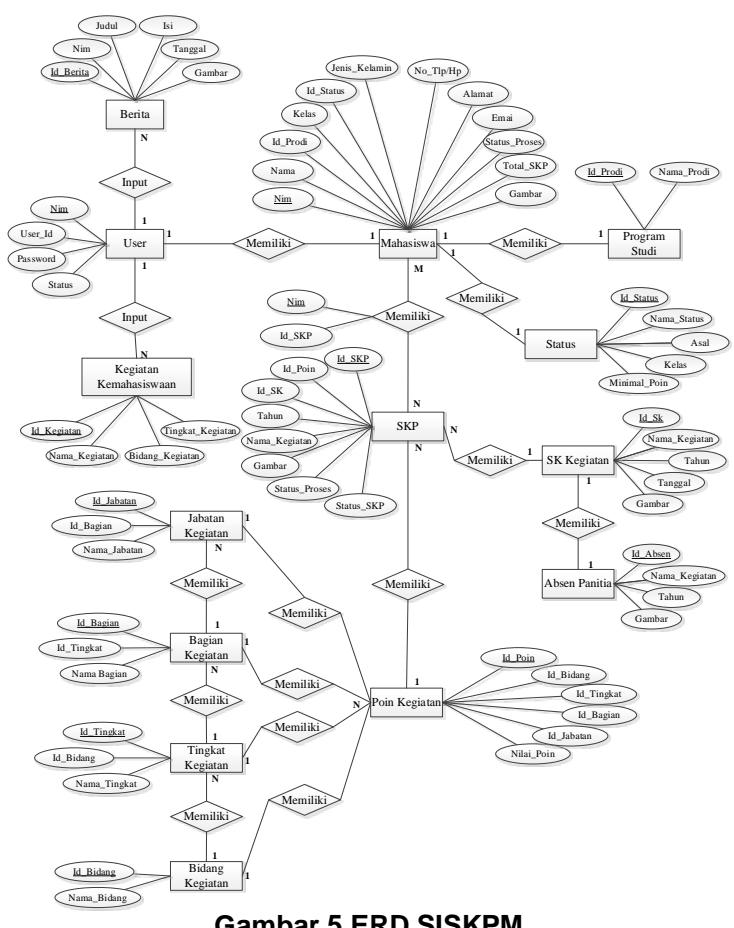

Gambar 5.ERD SISKPM

\subsection{Perancangan Database}

Adapun perancangan database dari Sistem Informasi Satuan Kredit Partisipasi Mahasiswa Fakultas Teknik Universitas Udayana ini akan ditampilkan dalam bentuk Entity Relationship Diagram (ERD) yang dapat dilihat pada Gambar 5. 
Seperti dilihat pada Gambar 5, database Sistem Informasi Satuan Kredit Partisipasi Mahasiswa Fakultas Teknik Universitas Udayana terdapat empat belas (14) buah entitas, masing-masing entitas memiliki beberapa field dan setiap entitas memiliki satu field primary key. Seperti contoh pada entitas berita, memiliki enam (6) buah field diantanya adalah id_berita, nim, judul, isi, tanggal dan Gambar. Field id berita menjadi primary key pada entitas ini, begitu juga pada entitasentitas lain yang ada.

\subsubsection{Metode Pengujian Sistem}

Metode pengujian yang akan digunakan dalam penelitian ini menggunakan metode pengujian System Usability Scale (SUS). Kuesioner SUS akan diberikan kepada dua puluh (20) user pengguna sistem yaitu dua (2) orang Komisi SKP Himpunan, satu (1) orang Komisi SKP SMFT, satu (1) orang Kemahasiswaan, satu (1) orang Ketua Kegiatan dan lima belas (15) orang mahasiswa. Kuesioner yang diberikan kepada dua puluh (20) orang responden terdiri dari 10 buah pernyataan yang dapat dilihat pada Tabel 1.

Tabel 1. Contoh Kuesioner SUS

\begin{tabular}{|c|c|c|c|c|c|c|}
\hline \multirow[t]{2}{*}{ No } & \multirow[t]{2}{*}{ Pernyataan } & $\begin{array}{l}\text { Sangat } \\
\text { Tidak } \\
\text { Setuju }\end{array}$ & & & & $\begin{array}{l}\text { Sangat } \\
\text { Setuju }\end{array}$ \\
\hline & & 1 & 2 & 3 & 4 & 5 \\
\hline 1 & $\begin{array}{l}\text { Saya pikir saya akan } \\
\text { sering menggunakan } \\
\text { website ini }\end{array}$ & & & & & \\
\hline 2 & $\begin{array}{l}\text { Menurut saya website ini } \\
\text { terlalu kompleks }\end{array}$ & & & & & \\
\hline 3 & $\begin{array}{l}\text { Saya pikir website ini } \\
\text { mudah digunakan }\end{array}$ & & & & & \\
\hline 4 & $\begin{array}{l}\text { Saya pikir saya butuh } \\
\text { bantuan orang teknik } \\
\text { untuk bisa menggunakan } \\
\text { website ini }\end{array}$ & & & & & \\
\hline 5 & $\begin{array}{l}\text { Beragam fungsi di } \\
\text { website ini sudah } \\
\text { terintegrasi dengan baik }\end{array}$ & & & & & \\
\hline 6 & $\begin{array}{l}\text { Saya pikir terlalu banyak } \\
\text { hal di website ini yang } \\
\text { tidak konsekuen }\end{array}$ & & & & & \\
\hline 7 & $\begin{array}{l}\text { Saya membayangkan } \\
\text { kebanyakan orang akan } \\
\text { dengan cepat } \\
\text { mempelajari penggunaan } \\
\text { website ini }\end{array}$ & & & & & \\
\hline 8 & $\begin{array}{l}\text { Saya pikir website ini } \\
\text { sangat tidak praktis }\end{array}$ & & & & & \\
\hline 9 & $\begin{array}{l}\text { Website ini begitu mudah } \\
\text { digunakan sehingga saya } \\
\text { merasa percaya diri } \\
\text { menggunakannya }\end{array}$ & & & & & \\
\hline 10 & $\begin{array}{l}\text { Saya perlu belajar } \\
\text { banyak tentang website } \\
\text { ini agar bisa } \\
\text { menggunakannya } \\
\text { dengan efektif }\end{array}$ & & & & & \\
\hline
\end{tabular}

\section{HASIL DAN PEMBAHASAN}

\subsection{Hasil}

Rancangan Sistem Informasi Satuan Kredit Partisipasi Mahasiswa Fakultas Teknik Universitas Udayana setelah direalisasikan dengan menggunakan bahasa pemrograman PHP dan HTML menggunakan responsive web design framework Bootstrap dan database MySQL. Sistem Informasi Satuan Kredit Partisipasi Mahasiswa Fakultas Teknik Universitas Udayana yang dibangun dapat menangani proses penginputan SKP lebih baik dan lebih cepat daripada menggunakan proses penginputan SKP secara manual.

Pada tahap desain sistem, terdapat beberapa buah tampilan yang dihasilkan pada Sistem Informasi Satuan Kredit Partisipasi Mahasiswa Fakultas Teknik Universitas Udayana, antara lain tampilan halaman awal, tampilan halaman input data SKP, tampilan halaman approve data SKP, tampilan halaman proses SKP mahasiswa, tampilan print-out data SKP mahasiswa dan tampilan halaman awal SISKPM yang diakses menggunakan Smartphone.Adapun tampilan halaman awal dari Sistem Informasi Satuan Kredit Partisipasi Mahasiswa Fakultas Teknik Universitas Udayana yang dapat dilihat pada Gambar 6.

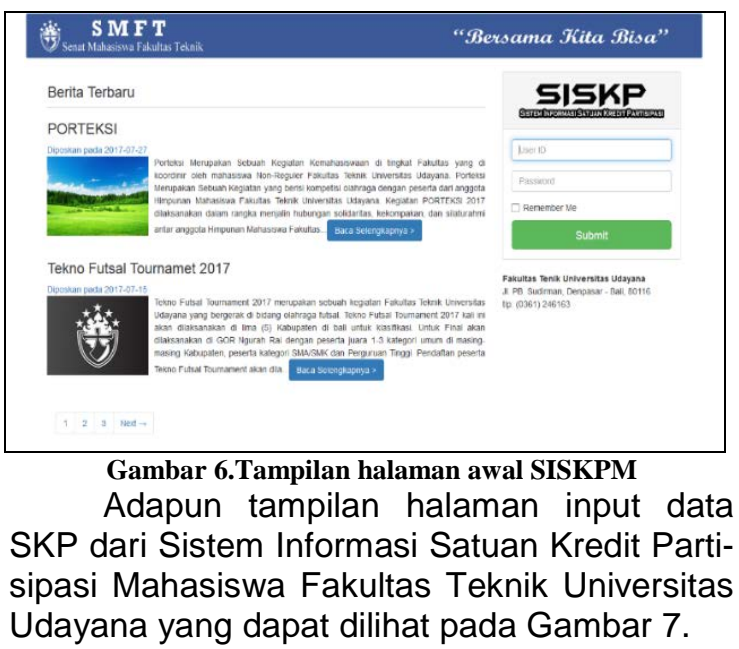




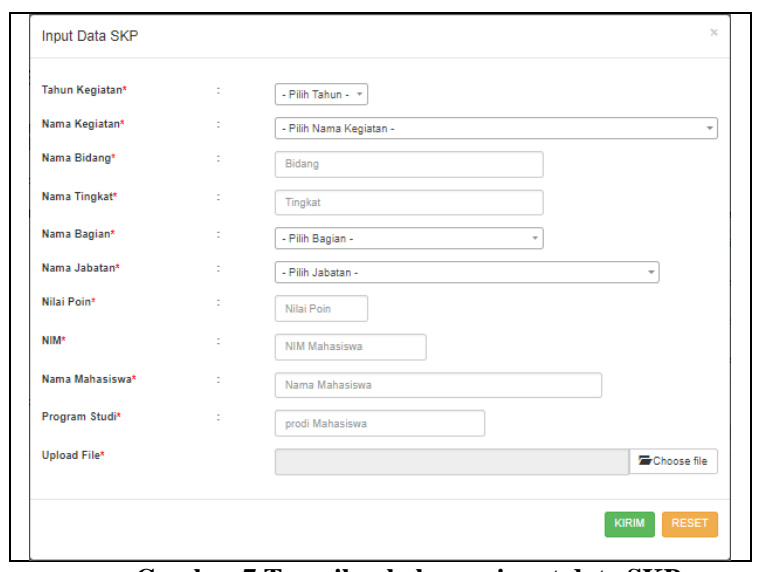

Gambar 7.Tampilan halaman input data SKP

Adapun tampilan halaman approve data SKP dari Sistem Informasi Satuan Kredit Partisipasi Mahasiswa Fakultas Teknik Universitas Udayana yang dapat dilihat pada Gambar 8.

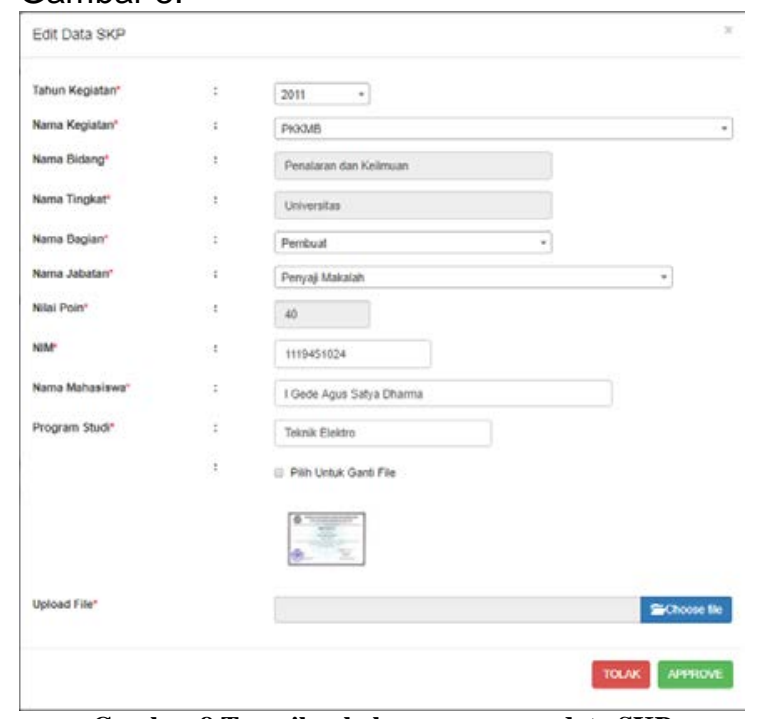

Gambar 8.Tampilan halaman approve data SKP

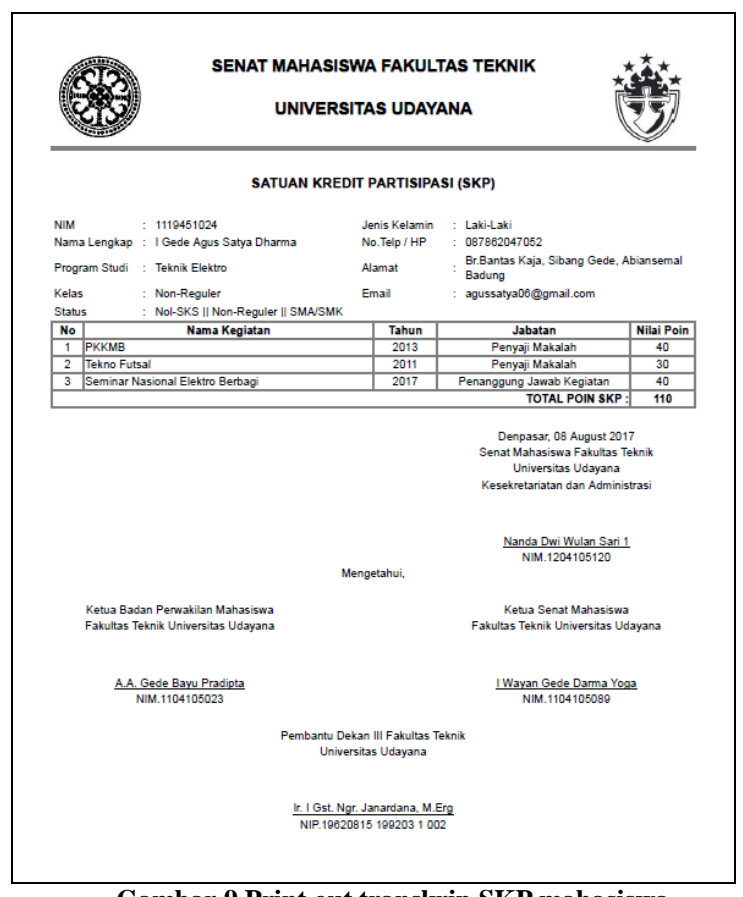

Gambar 9.Print out transkrip SKP mahasiswa

Sedangkan pada Gambar 9 diatas adalah contoh hasil print out transkrip SKP mahasiswa yang dihasilkan dari Sistem Informasi Satuan Kredit Partisipasi Mahasiswa Fakultas Teknik Universitas Udayana. Print out transkrip SKP mahasiswa inilah yang nantinya akan dijadikan sebagai bukti bahwa mahasiswa yang bersangkutan sudah menyelesaikan kewajiban memenuhi perolehan SKP di Fakultas Teknik Universitas Udayana, sehingga mahasiswa yang bersangkutan dapat mengikuti yudisium di Fakultas Teknik Universitas Udayana. 


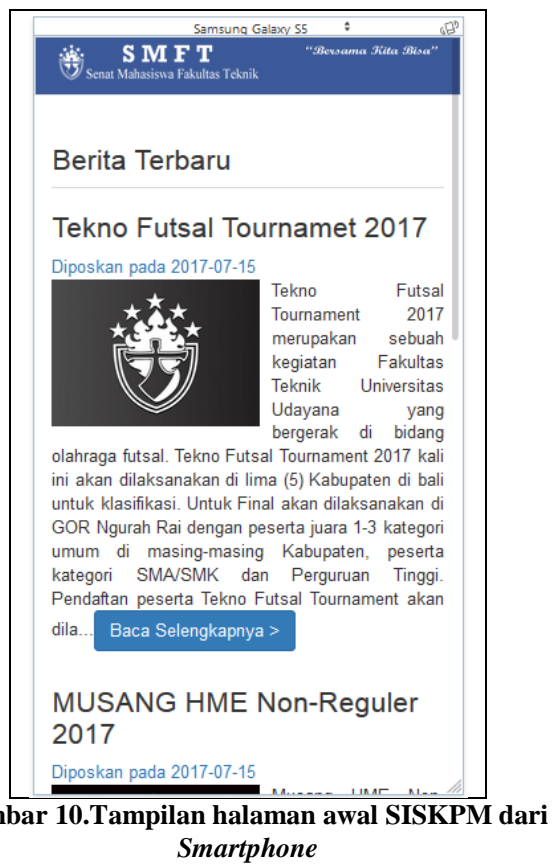

Tampilan halaman awal Sistem Informasi Satuan Kredit Partisipasi Mahasiswa Fakultas Teknik Universitas Udayana yang diakses menggunakan Smartphone memiliki tampilan yang responsive atau dapat menyesuaikan tampilan secara otomatis sesuai dengan ukuran layar perangkat yang digunakan untuk mengakses sistem. Tampilan halaman awal yang diakses menggunakan smartphone dapat dilihat pada Gambar 10.

\subsection{Pembahasan}

Pada pembahasan aplikasi ini akan membahas bagaimana cara kerja dari sistem informasi satuan kredit partisipasi mahasiswa Fakultas Teknik Universitas Udayana.

Pertama, Bagian Kemahasiswaan menginputkan data SK kegiatan yang akan dijadikan acuan dalam penginputan SKP. Kemudian Komisi SKP SMFT menginputkan data SKP mahasiswa sesuai data SK kegiatan yang dapat dilihat seperti Gambar 7. Selanjutnya mahasiswa melakukan proses data SKP dengan cara mengklik tombol proses yang berwarna merah sehingga data SKP mahasiswa secara otomatis dapat di approve oleh komisi SKP SMFT seperti Gambar 11.

Setelah mahasiswa melakukan proses data SKP, kemudian Komisi SKP Himpunan akan memvalidasi berupa approve data SKP seperti Gambar 8. Setelah data SKP di approve oleh Komisi SKP Himpunan, maka Komisi SKP SMFT melakukan proses cetak tranksrip SKP yang menghasilkan transkrip
SKP mahasiswa seperti Gambar 9. Transkrip SKP yang sudah tercetak kemudian ditandatangani oleh Komisi SKP SMFT, Ketua SMFT dan Ketua BPMFT. Setelah transkrip SKP ditandatangani, transkrip SKP diserahkan kepada mahasiswa untuk memperoleh tanda tangan dari Pembantu Dekan III Fakultas Teknik Universitas Udayana. Dengan sudah dilengkapinya seluruh tanda tangan yang ada di transkrip SKP, maka proses penginputan data SKP mahasiswa sudah selesai dilakukan.

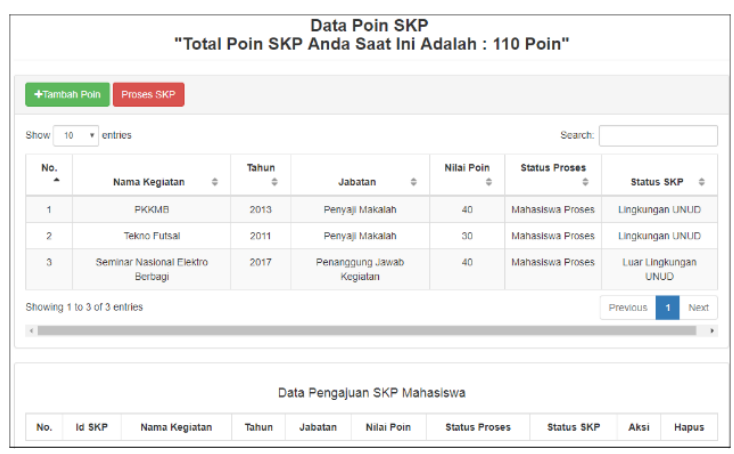

Gambar 11.Tampilan halaman proses skp mahasiswa Tabel 2. Hasil pengujian SISKPM dengan System Usability Scale (SUS)

\begin{tabular}{|c|c|c|c|c|c|c|c|c|c|c|c|c|c|c|}
\hline & \multicolumn{10}{|c|}{ Pernvataan Nomor } & \multirow{2}{*}{ Total } & \multirow[t]{2}{*}{$\begin{array}{l}\text { Nilai } \\
\text { SUS }\end{array}$} & \multirow{2}{*}{$\begin{array}{l}\text { Rata-Rata } \\
\text { Nilai SUS }\end{array}$} \\
\hline & & 1 & 2 & 3 & 4 & 5 & 6 & 7 & 8 & 9 & 10 & & & \\
\hline \multirow{22}{*}{ 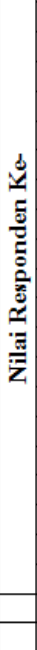 } & \begin{tabular}{|l|}
1 \\
\end{tabular} & 3 & 3 & 4 & 1 & 4 & 4 & 3 & 4 & 3 & 2 & 31 & 77.5 & \multirow{20}{*}{80.88} \\
\hline & 2 & 4 & 3 & 4 & 0 & 2 & 2 & 4 & 4 & 4 & 2 & 29 & 72.5 & \\
\hline & 3 & 3 & 1 & 4 & 1 & 3 & 3 & 2 & 3 & 4 & 1 & 25 & 62.5 & \\
\hline & 4 & 3 & 1 & 4 & 4 & 3 & 3 & 3 & 4 & 3 & 3 & 31 & 77.5 & \\
\hline & \begin{tabular}{|l|}
5 \\
\end{tabular} & 3 & 2 & 4 & 3 & 4 & 3 & 3 & 4 & 3 & 3 & 32 & 80 & \\
\hline & \begin{tabular}{|l}
6 \\
\end{tabular} & 4 & 3 & 4 & 4 & 3 & 3 & 4 & 4 & 3 & 3 & 35 & 87.5 & \\
\hline & 7 & 4 & 2 & 4 & 4 & 3 & 3 & 3 & 3 & 3 & 3 & 32 & 80 & \\
\hline & 8 & 3 & 2 & 4 & 3 & 4 & 4 & 3 & 3 & 3 & 2 & 31 & 77.5 & \\
\hline & 9 & 4 & 2 & 3 & 3 & 3 & 4 & 4 & 3 & 4 & 2 & 32 & 80 & \\
\hline & \begin{tabular}{|l|}
10 \\
\end{tabular} & 4 & 3 & 4 & 4 & 4 & 4 & 4 & 4 & 4 & 3 & 38 & 95 & \\
\hline & \begin{tabular}{|l|}
11 \\
\end{tabular} & 3 & 2 & 4 & 3 & 2 & 3 & 4 & 4 & 4 & 4 & 33 & 82.5 & \\
\hline & 12 & 2 & 4 & 4 & 4 & 2 & 4 & 4 & 4 & 3 & 3 & 34 & 85 & \\
\hline & 13 & 3 & 3 & 4 & 2 & 4 & 4 & 3 & 4 & 3 & 3 & 33 & 82.5 & \\
\hline & 14 & 3 & 3 & 4 & 1 & 4 & 4 & 3 & 4 & 3 & 3 & 32 & 80 & \\
\hline & 15 & 2 & 2 & 3 & 3 & 3 & 3 & 3 & 4 & 4 & 3 & 30 & 75 & \\
\hline & 16 & 3 & 3 & 4 & 4 & 2 & 4 & 4 & 4 & 4 & 3 & 35 & 87.5 & \\
\hline & 17 & 4 & 3 & 4 & 3 & 3 & 3 & 4 & 4 & 4 & 4 & 36 & 90 & \\
\hline & \begin{tabular}{|l|}
18 \\
\end{tabular} & 4 & 3 & 4 & 4 & 2 & 4 & 4 & 4 & 4 & 3 & 36 & 90 & \\
\hline & 19 & 2 & 2 & 3 & 3 & 3 & 3 & 3 & 4 & 4 & 3 & 30 & 75 & \\
\hline & 20 & 3 & 1 & 4 & 3 & 3 & 3 & 4 & 4 & 4 & 3 & 32 & 80 & \\
\hline & & 64 & 48 & 77 & 57 & 61 & 68 & 69 & 76 & 71 & 56 & \multicolumn{3}{|c|}{ Total } \\
\hline & & 70 & 53 & 85 & 63 & 67 & 75 & 76 & 84 & 78 & 62 & \multicolumn{3}{|c|}{ Nilai Pernyataan } \\
\hline
\end{tabular}

Pada penelitian yang dilakukan ini menggunakan metode pengujian System Usability Scale (SUS). Dimana pengujian aplikasi ini dilakukan dengan memberikan 10 buah pertanyaan kepada 20 user/pengguna sistem SKP.

Hasil pengujian sistem SISKPM ini dapat dilihat pada Tabel 2 .

Hasil dari pengujian System Usability Scale (SUS) tersebut memperoleh nilai 80,88 . 
Hasil tersebut menunjukkan bahwa sistem memiliki tingkat usabilitas diatas rata-rata karena berada di atas angka 68. Berdasarkan nilai SUS tersebut, maka Sistem Informasi Satuan Kredit Partisipasi Mahasiswa Fakultas Teknik Universitas Udayana yang dibangun memiliki nilai SUS 80,88 yang berarti:

$$
\begin{array}{ll}
\text { Adjective Ratings } & =\text { Excellent } \\
\text { Grade Scale } & =B \\
\text { Acceptability Ranges } & =\text { Acceptable }
\end{array}
$$

\section{SIMPULAN}

Berdasarkan hasil dan pembahasan yang dilakukan tentang Sistem Informasi Satuan Kredit Partisipasi Mahasiswa Fakultas Teknik Universitas Udayana maka dapat disimpulkan beberapa hal sebagai berikut :

1. Rancangan Sistem Informasi Satuan Kredit Partisipasi Mahasiswa Fakultas Teknik Universitas Udayana bisa dibangun dengan tahapan identifikasi permasalahan yang ada, kemudian melakukan perumusan masalah dan tujuan penelitian, kemudian dilakukan studi lapangan, studi pustaka, kemudian dilakukan pengumpulan data, melakukan perancangan konsep sistem yang akan dibangun, kemudian membuat perancangan database yang akan digunakan menggunakan DBMS MySQL, kemudian aplikasi dibangun dengan menggunakan bahasa pemrograman HTML dan PHP dengan menggunakan framework bootstrap.

2. Sistem Informasi Satuan Kredit Partisipasi Mahasiswa Fakultas Teknik Universitas Udayana yang dibangun menggunakan framework bootstrap memiliki tampilan yang responsive, dimana tampilan sistem secara otomatis menyesuaikan diri dengan ukuran layar perangkat yang digunakan untuk mengakses sistem.

3. Pengujian Sistem Informasi Satuan Kredit Partisipasi Mahasiswa Fakultas Teknik Universitas Udayana menggunakan metode system usability scale (SUS) yang diberikan kepada dua puluh (20) respoden dan memperoleh nilai rata-rata 80,88 . Berdasarkan nilai rata-rata SUS tersebut, maka dapat diartikan Sistem Informasi Satuan Kredit Partisipasi Mahasiswa Fakultas Teknik Universitas Udayana yang dibangun memiliki nilai Adjective Ratings= Excellent, Grade Scale $=B$ dan Acceptability Ranges=Acceptable.
4. Diharapkan kedepannya Sistem Informasi Satuan Kredit Partisipasi Mahasiswa Fakultas Teknik Universitas Udayana ini dapat melakukan proses pendaftaran panitia kegiatan kemahasiswaan Fakultas Teknik Universitas Udayana secara online.

\section{Daftar Pustaka}

[1] SMFT UNUD. 2012. Buku Pedoman Satuan Kredit Partisipasi. Bukit Jimbaran.

[2] Sukarata,P.G. 2015. Pembuatan Sistem Informasi Satuan Kredit Kegiatan Mahasiswa (SKKM) Politeknik Negeri Bali (PNB) Berbasis Web.

[3] Jogiyanto. 2005. Analisis \& Desain.Yogyakarta: Andi Offset.

[4] Abdulloh, R. 2015. Web Programming is Easy. Jakarta : Elex Media Komputindo.

[5] Nielsen, J. 2003. Usability 101 : Introduction to usability.

[6] Brooke, John. (1996). SUS - A quick and dirty usability scale. Beaconsfield : Redhatch Consulting Ltd.

[7] Bangor,A. Miller,J. Kortum,P. 2009. Determining What Individual SUS Scores Mean: Adding an Adjective Rating Scale., 4(3,4):119-121. 